New Perspectives in German Political Studies

General Editors: William Paterson OBE is Honorary Professor in German and European Politics at the University of Aston and Chairman of the German British Forum.

Charlie Jeffery is Professor of Politics at the University of Edinburgh.

Germany remains a pivotal country in Europe. It is Europe's biggest economy, continues to play a central role in the European Union, and has a growing significance in international security politics based on its strategic location at the centre of Europe and its evolving role as a provider of security in Europe and beyond. All this is nuanced by the legacies of a turbulent recent history: the two World Wars, the Holocaust, Germany's division after World War II and its unification in 1990.

New Perspectives in German Political Studies has been designed as a platform for debate and scholarship on contemporary Germany. It welcomes contributions from political science, international relations, political economy and contemporary history. It follows on from the success of the earlier series on New Perspectives in German Studies, co-edited by William Paterson and the late Professor Michael Butler.

Titles include:

Ed Turner

POLITICAL PARTIES AND PUBLIC POLICY IN THE GERMAN LÄNDER

When Parties Matter

Timo Fleckenstein

INSTITUTIONS, IDEAS AND LEARNING IN WELFARE STATE CHANGE

Labour Market Reforms in Germany

Alister Miskimmon, William E. Paterson and James Sloam (editors)

GERMANY'S GATHERING CRISIS

The 2005 Federal Election and the Grand Coalition

Anne Fuchs

PHANTOMS OF WAR IN CONTEMPORARY GERMAN LITERATURE, FILMS AND

DISCOURSE

The Politics of Memory

Beverly Crawford

POWER AND GERMAN FOREIGN POLICY

Embedded Hegemony in Europe

Dan Hough, Michael Koß and Jonathan Olsen

THE LEFT PARTY IN CONTEMPORARY GERMAN POLITICS

Roger Woods

GERMANY'S NEW RIGHT AS CULTURE AND POLITICS

Christian Schweiger

BRITAIN, GERMANY AND THE FUTURE OF THE EUROPEAN UNION 
Matthew M.C. Allen

THE VARIETIES OF CAPITALISM PARADIGM

Explaining Germany's Comparative Advantage?

Gunther Hellmann (editor)

GERMANY'S EU POLICY IN ASYLUM AND DEFENCE

De-Europeanization by Default?

Charles Lees

PARTY POLITICS IN GERMANY

A Comparative Politics Approach

Ronald Speirs and John Breuilly (editors)

GERMANY'S TWO UNIFICATIONS

Anticipations, Experiences, Responses

James Sloam

THE EUROPEAN POLICY OF THE GERMAN SOCIAL DEMOCRATS

Interpreting a Changing World

Margarete Kohlenbach

WALTER BENJAMIN

Self-Reference and Religiosity

Henning Tewes

GERMANY, CIVILIAN POWER AND THE NEW EUROPE

Enlarging Nato and the European Union

Wolf-Dieter Eberwein and Karl Kaiser (editors)

GERMANY'S NEW FOREIGN POLICY

Decision-Making in an Interdependent World

Ruth Wittlinger

GERMAN NATIONAL IDENTITY IN THE TWENTY-FIRST CENTURY

A Different Republic After All?

Chantal Lacroix

IMMIGRANTS, LITERATURE AND NATIONAL INTEGRATION

Gerard Braunthal

RIGHT-WING EXTREMISM IN CONTEMPORARY GERMANY

New Perspectives in German Political Studies

Series Standing Order ISBN 978-0-333-92430-3 hardcover

Series Standing Order ISBN 978-0-333-92434-1 paperback

(outside North America only)

You can receive future titles in this series as they are published by placing a standing order. Please contact your bookseller or, in case of difficulty, write to us at the address below with your name and address, the title of the series and the ISBN quoted above.

Customer Services Department, Macmillan Distribution Ltd, Houndmills, Basingstoke, Hampshire RG21 6XS, England 


\section{Political Parties and Public Policy in the German Länder}

When Parties Matter

Ed Turner

Lecturer in Politics, Department of Politics and International Relations, Aston University, $U K$ 


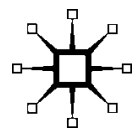

(c) Ed Turner 2011

Softcover reprint of the hardcover 1st edition 2011 978-0-230-28442-5

All rights reserved. No reproduction, copy or transmission of this publication may be made without written permission.

No portion of this publication may be reproduced, copied or transmitted save with written permission or in accordance with the provisions of the Copyright, Designs and Patents Act 1988, or under the terms of any licence permitting limited copying issued by the Copyright Licensing Agency, Saffron House, 6-10 Kirby Street, London EC1N 8TS.

Any person who does any unauthorized act in relation to this publication may be liable to criminal prosecution and civil claims for damages.

The author has asserted his right to be identified as the author of this work in accordance with the Copyright, Designs and Patents Act 1988.

First published 2011 by

PALGRAVE MACMILLAN

Palgrave Macmillan in the UK is an imprint of Macmillan Publishers Limited, registered in England, company number 785998, of Houndmills, Basingstoke, Hampshire RG21 6XS.

Palgrave Macmillan in the US is a division of St Martin's Press LLC, 175 Fifth Avenue, New York, NY 10010.

Palgrave Macmillan is the global academic imprint of the above companies and has companies and representatives throughout the world.

Palgrave ${ }^{\circledR}$ and Macmillan ${ }^{\circledR}$ are registered trademarks in the United States, the United Kingdom, Europe and other countries

\section{ISBN 978-1-349-32959-5 \\ ISBN 978-0-230-30794-0 (eBook) \\ DOI $10.1057 / 9780230307940$}

This book is printed on paper suitable for recycling and made from fully managed and sustained forest sources. Logging, pulping and manufacturing processes are expected to conform to the environmental regulations of the country of origin.

A catalogue record for this book is available from the British Library.

Library of Congress Cataloging-in-Publication Data

Turner, Edward, 1977-

Political parties and public policy in the German Länder : when parties matter / Ed Turner.

p. $\mathrm{cm}$.

Includes bibliographical references and index.

1. Political parties-Germany-States. 2. Political planning-

Germany-States. 3. Political parties-Germany-States-Case studies.

4. Political planning-Germany-States-Case studies. 5. State governments-Germany. I. Title.

JN3971.A988T87 2011

324.243-dc22

2011012478

$\begin{array}{rrrrrrrrrr}10 & 9 & 8 & 7 & 6 & 5 & 4 & 3 & 2 & 1\end{array}$

$\begin{array}{llllllllll}20 & 19 & 18 & 17 & 16 & 15 & 14 & 13 & 12 & 11\end{array}$




\section{Contents}

List of Tables vi

Acknowledgements vii

Preface viii

Chapter 1 Introduction: Partisan Influence Upon Public Policy in 1 Decentralised Polities

Chapter 2 Do Parties Matter in the German Länder? Theoretical 17 and Practical Challenges, Past Attempts at Exploration, and a New Approach

Chapter 3 Contemporary German Federalism

Chapter 4 Education, Family and Childcare, and Labour Market $\quad 50$ Policies at a Land Level

Chapter 5 The Case of Hesse 1999-2003 76

Chapter 6 The Saarland 1999-2004 125

$\begin{array}{lll}\text { Chapter } 7 & \text { Saxony-Anhalt 2002-2006 } & 165\end{array}$

$\begin{array}{lll}\text { Chapter } 8 \text { Conclusion } & 219\end{array}$

Appendix 1 Bibliography 230

Appendix 2 List of Interviews 253

Appendix 3 Commonly Used German Terms and Abbreviations 255

$\begin{array}{ll}\text { Index } & 257\end{array}$ 


\section{List of Tables}

1.1 Majoritarian vs. Consensus democracy 9

4.1 Two paradigms of education policy 62

4.2 Available places in childcare institutions: \% of children 64 for whom a place was available

4.3 Two paradigms of childcare and family policy 67

4.4 Two paradigms of labour market policy 75

5.1 Unemployment in Hesse 1999-2003 77

$\begin{array}{ll}5.2 & \text { Landtag election results in Hesse 1946-2003 }\end{array}$

5.3 Land governments in Hesse 1946-2007 80

5.4 Number of Förderstufen and pupils in Förderstufen in 95 Hesse 1999-2004

5.5 Number of comprehensive schools and pupils attending 96 them 1999-2004

5.6 Education policy in Hesse 1999-2003 106

5.7 Family and childcare policy in Hesse 1999-2003 114

5.8 Labour market policy in Hesse 1999-2003 122

6.1 Unemployment in Saarland 1999-2004 127

6.2 Landtag election results (\%) in the Saarland 1960-2004 128

6.3 Land governments in the Saarland 1959-2007 128

6.4 Number of schools and pupils by school type 136 (selected schools in the Saarland, 2000-2005)

6.5 Education policy change in the Saarland 1999-2004 145

6.6 Provision of institutional childcare 1980-2005 150

6.7 Family and childcare policy in the Saarland 1999-2004 153

6.8 Labour market policy in the Saarland 1999-2004 160

7.1 Population development in Saxony-Anhalt (actual or 166 projected, as at $1^{\text {st }}$ January 2007)

7.2 Age breakdown of population in Saxony-Anhalt 167

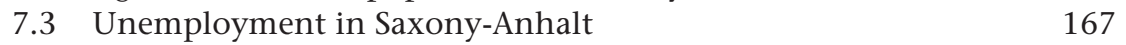

7.4 Election results in Saxony-Anhalt 1990-present 170 (results of list votes)

$\begin{array}{lll}7.5 & \text { Education policy in Saxony-Anhalt } & 192\end{array}$

7.6 Childcare policy in Saxony-Anhalt 204

7.7 Labour market policy in Saxony-Anhalt 216 


\section{Acknowledgements}

This book is the culmination of several years' work on German politics, and could not have been written without a great deal of support from friends, family, and colleagues.

I am extremely grateful to both the Economic and Social Research Council, and subsequently the University of Birmingham, for financial support.

I am also very grateful to officials, politicians and other professionals who took time out of hectic schedules to discuss the issues addressed in this study.

Colleagues and friends at Birmingham University's Institute for German Studies provided a great deal of help. Special thanks are owed to William Paterson and Thomas Poguntke for reading sections of the manuscript and offering very helpful advice.

Thanks are also due to Otto Wurbs, Adelheid Mallach and Nadine Müller for putting me up (and putting up with me!) while I was undertaking fieldwork, as well as providing many useful suggestions and impulses. Nadine Greulich was also very kind and hospitable. Antonia Bance generously looked after my commitments in Oxford while I was away on fieldwork. Especially in the early years, my friends Siobhan McAndrew and Rick Muir were a frequent source of guidance, entertainment, inspiration and delay to progress!

My interest in policy change at the sub-national level in Germany developed during a spell at the Geschwister-Scholl Institute in Munich in 1998-99. I am particularly grateful to Florian Bieberbach, Florian Sipek, Christoph Moosbauer, Ulrike Boesser, and Nikolaus Gradl for their camaraderie during this time, and for demonstrating the deep-rooted convictions on which subnational political engagement can be based.

Particular thanks are due to Charlie Jeffery, for his help in the early stages of this study, and to Simon Green throughout, for never-ending patience in dealing with a recalcitrant colleague, and keeping faith in him until the bitter end.

On a personal as well as a professional note, I owe a debt of thanks to Dan Paskins, Bill Turner, and particularly Anneliese Dodds, for discussing the ideas in this study, proof-reading beyond the call of duty, and much more besides. I am also very grateful to Frank Pattison for turning me Germanophile.

The editorial team and all the production staff at Palgrave Macmillan have been wonderful and I am indebted to them for all their patient assistance.

Finally, a debt of thanks is due to my parents. In different ways, they prompted and fostered my interests in both academic study and politics, and it is a source of sadness that they will not see this book. It does not do them justice. 


\section{Preface}

All translations, unless otherwise stated, are by the author. Where there is a reference to the 'Statistisches Bundesamt' or 'Statistisches Landesamt', this refers to the relevant statistical office's publicly available data sets. Official publications (such as official records of laws, regulations and decrees, and stenographic reports of parliamentary sessions) are publicly available and are referred to in the text but not separately in the Bibliography. Election results and details of government composition are available from the relevant state government and state election officer. 